\title{
Response of Pearl Millet to Weather Health Indices under Different Spacings and Sowing Windows in Coastal Agro- Ecosystem of Andhra Pradesh, India
}

\author{
B. Swathi*, V. R. K. Murthy, M. Sree Rekha and K. JayaLalitha \\ Department of Agronomy, Agricultural College, Bapatla-522101, India \\ *Corresponding author
}

\section{A B S T R A C T}

\section{Keywords}

Pearl millet, GDD, HTU, PTU, HUE, HtUE, PtUE, Sowing windows, grain yield

\section{Article Info}

Accepted: 22 March 2020 Available Online: 10 April 2020
A field experiment was conducted during kharif, 2018 at Agricultural College Farm, Bapatla to study the phenology and various weather health indices of pearlmillet grown under different spacings and dates of sowing. The crop sown on $2^{\text {nd }}$ fortnight of July accumulated maximum growing degree days, photo thermal units, heat use efficiency, helio thermal use efficiency and photo thermal use efficiency whereas the highest helio thermal units were recorded under $2^{\text {nd }}$ fortnight of August sowing to attain different phenological stages till maturity. Among different spacings, $45 \times$ $15 \mathrm{~cm}$ treatment accumulated highest growing degree days, helio thermal units and photo thermal units, heat use efficiency, helio thermal use efficiency and photo thermal use efficiency as compared to other.

\section{Introduction}

Pearl millet (Pennisetum glaucum), which belongs to the family poaceae, is one of the most important among the major millets which are generally referred as nutritious coarse grain cereals. It is one of the oldest food crops known to man and possibly first cereal grain to be used for domestic purposes (Railey, 2006). It is grown mostly in marginal areas under where major cereals fail to give substantial yields.
Among the cereals of the world, its rank is sixth which is next to rice, wheat, corn, barley, and sorghum. In Andhra Pradesh, area under pearl millet is 0.042 million ha and its production is 0.072 million tonnes with an average productivity of $1718 \mathrm{~kg} \mathrm{ha}{ }^{-1}$ (www.Indiastat.com, 2016-17).

Temperature is an important environmental factor influencing the growth and development of crop plants. It influences the crop phenology and yield of crop. The 
optimum range of air temperature for vegetative growth of pearl millet is 33 to $34^{\circ} \mathrm{c}$. Soil temperatures should be at least $18^{\circ} \mathrm{C}$ or warmer before pearl millet is sown and it germinates well at soil temperatures of 21 to $31^{\circ} \mathrm{C}$. Grain production in pearl millet is known to be adversely affected when flowering and grain setting coincide with rains and low temperatures, respectively. Generally, low yields of pearlmillet are noticed under late sown situations coupled with aberrant monsoon behavior of its early cessation.

Sowing window and weather are the most important non - monetary inputs which influence crop yield even in photo and thermo- insensitive crops. A decline in both temperature and length of photo period over successive sowing dates from July to September had a drastic effect on phenology and yield potentials of the pearl millet (Mass et al., 2007). Late sowing beyond October may result in poor germination and plant stand due to low soil temperatures.

Besides weather factors viz., temperature and rainfall, inadequate plant population also attributes to the lower yields of pearl millet. As the yield of a crop depends on its stand establishment and final plant density which in turn depends on the germination percentage and the survival rate. Yield can be increased by optimizing the plant population. Hence, a field experiment was carried to study the effect of different spacings and sowing dates on the phenology, heat units and heat efficiencies required for pearlmillet.

\section{Materials and Methods}

The present research was carried on sandy loamy soils of Agricultural College Farm, Bapatla, during kharif, 2018. The experimental soil was sandy loam having $\mathrm{pH}$ 6.80 and organic carbon of 0.21 per cent. The available nitrogen, phosphorus and potassium contents were $240,12.8$, and $188.1 \mathrm{~kg} \mathrm{ha}^{-1}$, respectively. The experiment was conducted in factorial RBD with three replications.

Twelve treatment combinations were formed considering different spacings i.e., $45 \times 15 \mathrm{~cm}$ $\left(\mathrm{S}_{1}\right), 45 \times 30 \mathrm{~cm}\left(\mathrm{~S}_{2}\right), 60 \times 15 \mathrm{~cm}\left(\mathrm{~S}_{3}\right)$ and 60 $\times 30 \mathrm{~cm}\left(\mathrm{~S}_{4}\right)$ and sowing windows i.e., $2^{\text {nd }}$ fortnight of July $\left(\mathrm{D}_{1}\right), 1^{\text {st }}$ fortnight of August $\left(D_{2}\right)$ and $2^{\text {nd }}$ fortnight of August $\left(D_{3}\right)$.

During the crop growth period, the weekly mean maximum temperature ranged from $29.9^{\circ} \mathrm{C}$ to $37.6^{\circ} \mathrm{C}$ with an average of $33.3^{\circ} \mathrm{C}$ and weekly mean minimum temperature ranged from $18.77^{\circ} \mathrm{C}$ to $26.80{ }^{\circ} \mathrm{C}$ with an average of $24.2^{\circ} \mathrm{C}$. The weekly mean relative humidity ( $8.30 \mathrm{hrs}$.) ranged from 65.8 to $86.7 \%$ with an average of $80.3 \%$ and weekly mean relative humidity (17.30 hrs.) ranged from 47.1 to $83.7 \%$ with an average of $71.5 \%$. A total rainfall of $387.4 \mathrm{~mm}$ was received in 25 rainy days during the crop growth period. The weekly mean bright sunshine hours ranged from 0.78 to 6.89 hours day $^{-1}$ with an average of 5 hours day ${ }^{-1}$. The weekly mean day length ranged from 11.26 to 12.89 hours day $^{-1}$. All the data recorded in the study were subjected to statistical analysis using ANOVA for factorial RBD suggested by Panse and Sukkhatme (1985).

The growth stages (phenophases) of pearl millet were divided as follows to have a better understanding of the influence of weather health indices on pearlmillet.

Phase 1: GS1 - Sowing to panicle differentiation

Phase 2: GS2 - Panicle initiation to flowering Phase 3: GS3 - Flowering to grain maturity Growing degree days (GDD)

A degree day or a heat unit is the departure from the mean daily temperature above the 
threshold temperature of the crop. Growing degree days were computed from date of sowing to harvesting of the crop to give accumulated growing degree days. This was expressed as ${ }^{0} \mathrm{C}$ day. The GDD were calculated by using the following equation (Iwata, 1984).

Growing Degree Days (GDD) $=\frac{\mathrm{T}_{\max }+\mathrm{T}_{\min }}{2}-\mathrm{T}_{\mathrm{b}}$

Where,

$\mathrm{T}_{\text {max }}=$ Maximum temperature

$\mathrm{T}_{\min }=$ Minimum temperature

$\mathrm{T}_{\mathrm{b}}=$ Base temperature

\section{Helio thermal units (HTU)}

Heliothermal unit (HTU) was measured daily with the help of Campbell-stokes sunshine recorder. This was expressed as ${ }^{0} \mathrm{C}$ day hour. This was calculated by using the formula given by Rajput (1980).

Helio Thermal Units $($ HTU $)=$ GDD $\times$ Bright Sunshine Hours

\section{Photo thermal units (PTU)}

Nuttonson (1956) made an attempt to improve GDD concept applying day length factor and used Photothermal unit (PTU) concept in climatic analogue studies. This was expressed as ${ }^{0} \mathrm{C}$ day hour and calculated by using the formula

\section{Photo Thermal Units $(\mathrm{PTU})=$ GDD $\times$ Day length}

\section{Heat use efficiency (HUE)}

Heat use efficiency defined as yield per day ${ }^{0} \mathrm{C}$ on growing day concept or per unit of day ${ }^{0} \mathrm{C}$ hours on Helio thermal units indicating the efficiency with the available heat utilized for grain yields. This was expressed as $\mathrm{kg} \mathrm{ha}^{-1}{ }^{0} \mathrm{C}^{-}$ 1 day $^{-1}$ and was calculated by using the following formula (Haider et al., 2003).
Heat Use Efficiency (HUE) $=\frac{\text { Total drymatter or seed yield }\left(\mathrm{kg} \mathrm{ha}^{-1}\right)}{\text { Accumuated heat units }\left({ }^{\circ} \mathrm{C} \text { day }\right)}$

\section{Helio thermal use efficiency (HtUE)}

It is defined as total drymatter yield per hours ${ }^{0} \mathrm{C}$ on growing day concept or per unit of ${ }^{0} \mathrm{C}$ day hours on helio thermal units indicating the efficiency with the available sunshine hours utilized for drymatter yields. This was expressed as $\mathrm{kg} \mathrm{ha}^{-1}{ }^{0} \mathrm{C}^{-1}$ day $^{-1}$ hour and was calculated using the formula (Rajput, 1980)

HTUE $=\frac{\text { Total drymatter or seed yield }\left(\mathrm{kg} \mathrm{ha}^{-1}\right)}{\text { Helio thermal units (HTU) }}$

\section{Photo thermal use efficiency (PtUE)}

It is defined as total drymatter yield per hour ${ }^{0} \mathrm{C}$ on growing day concept or per unit of ${ }^{0} \mathrm{C}$ day hours on Photo thermal units which indicate the efficiency with the available day length utilized for drymatter yields. This was expressed as $\mathrm{kg} \mathrm{ha}^{-1} \mathrm{C}^{-1} \mathrm{day}^{-1}$ hour. This was calculated using the formula as suggested by Rajput (1980).

$$
\text { PtUE }=\frac{\text { Total drymatter or Seed yield }\left(\mathrm{kg} \mathrm{ha}^{-1}\right)}{\text { Photo Thermal Units (PTU) }}
$$

\section{Results and Discussion}

\section{Pearlmillet phenology}

The number of days taken to attain different phenophases from sowing to maturity ranged from 30 to 90 days for different spacings and dates of sowing. Among dates of sowing, $2^{\text {nd }}$ fortnight of July $\left(\mathrm{D}_{1}\right)$ took the maximum number of days of 90 to maturity (Table 1).

Among the spacings, the mean maximum days to attain all the phases were recorded with $45 \times 15 \mathrm{~cm}\left(\mathrm{~S}_{1}\right)$ followed by $60 \times 15 \mathrm{~cm}$ $\left(\mathrm{S}_{3}\right)$ and $45 \times 30 \mathrm{~cm}\left(\mathrm{~S}_{2}\right)$ and the least were recorded with $60 \times 30 \mathrm{~cm}\left(\mathrm{~S}_{4}\right)$. 


\section{Growing degree days (GDD)}

For different spacings and dates of sowing, the accumulated GDD from sowing to maturity during different phenophases ranged from 419 to 745 . Among the sowing dates, $D_{1}$ recorded the highest GDD (1903) followed by $\mathrm{D}_{2}(1888)$ and least were accumulated with $\mathrm{D}_{3}$ treatment (Table 1).

This might be due to longer crop duration with early sowing in July along with optimum temperatures and bright sunshine hours during vegetative and reproductive stage that favoured crop growth for accumulating higher GDD and thereby yield. Similar results were also reported by Bhuva and Detroja (2018) and Wankhede et al., (2018).

\section{Helio thermal units (HTU)}

The accumulated HTU from sowing to maturity during different phenophases for different spacings and dates of sowing ranged from 1244 to 4505 .

Among the four spacings and three dates of sowing, the accumulated HTU of spacing $45 \times 15 \mathrm{~cm}$ at $2^{\text {nd }} \mathrm{FN}$ of August sowing recorded highest (10320). This might be due to higher GDD accumulation during reproductive stage and also by the combined effect of higher bright sunshine hours and optimum temperatures during crop duration. Similar results were also reported by Padma and Subbaiah (2016) and Revathi and Sree Rekha (2016).

\section{Photo thermal units (PTU)}

The photo thermal units for different phenophases revealed that the accumulated photo thermal units from vegetative to maturity ranged from 4825 to $8724{ }^{\circ} \mathrm{C}$ day hr. for different spacings at different dates of sowing. The total accumulated PTU were highest during $2^{\text {nd }} \mathrm{FN}$ of July $\left(\mathrm{D}_{1}\right)$ sowing (23428) compared to other sowing dates (Table 1).

This might be due to the crop duration, higher bright sunshine hours, longer photoperiods, optimum temperatures during crop growth period and higher GDD and HTU during reproductive stage. The results are in agreement with Girijesh et al., (2011) and Patidar (2013).

Thermal use efficiencies of pearl millet under different dates of sowing and spacings

Pearlmillet sown on $2^{\text {nd }}$ fortnight of July recorded highest HUE, HtUE and PtUE with total drymatter accumulation and grain yield at different spacings. Maximum HUE of 5.45 $\mathrm{kg} \mathrm{ha}^{-1 \circ} \mathrm{C}^{-1}$ day $^{-1}$ for drymatter accumulation of $10373 \mathrm{~kg} \mathrm{ha}^{-1}$ and $1.52 \mathrm{~kg} \mathrm{ha}^{-1}{ }^{\circ} \mathrm{C}^{-1}$ day $^{-1}$ for grain yield of $2875 \mathrm{~kg} \mathrm{ha}^{-1}$ was recorded with $45 \times 15 \mathrm{~cm}\left(\mathrm{~S}_{1}\right)$ when sown on $2^{\text {nd }}$ fortnight of July $\left(\mathrm{D}_{1}\right)$ (Table 2).

The highest helio-thermal use efficiency of $1.27 \mathrm{~kg} \mathrm{ha}^{-1}{ }^{\circ} \mathrm{C}^{-1}$ day $^{-1}$ hour for drymatter accumulation of $10373 \mathrm{~kg} \mathrm{ha}^{-1}$ and 0.35 $\mathrm{kg} \mathrm{ha}^{-1}{ }^{\circ} \mathrm{C}^{-1}$ day $^{-1}$ hour for grain yield of 2875 $\mathrm{kg} \mathrm{ha}^{-1}$ were recorded with $45 \times 15 \mathrm{~cm}\left(\mathrm{~S}_{1}\right)$ when pearl millet was sown on $2^{\text {nd }}$ fortnight of July $\left(\mathrm{D}_{1}\right)$.

With regard to photo-thermal use efficiency, pearl millet with spacing $45 \times 15 \mathrm{~cm}\left(\mathrm{~S}_{1}\right)$ when sown on $2^{\text {nd }}$ fortnight of July $\left(D_{1}\right)$ recorded the maximum PtUE of $0.44 \mathrm{~kg} \mathrm{ha}^{-1}$ ${ }^{\circ} \mathrm{C}^{-1}$ day $^{-1}$ hour for drymatter accumulation and $0.12 \mathrm{~kg} \mathrm{ha}^{-1}{ }^{\circ} \mathrm{C}^{-1}$ day $^{-1}$ hour for grain yield and was followed by $S_{3}, S_{2}$ and $S_{4}$ spacings (Table 2). 
Table.1 Growing degree days $\left({ }^{0} \mathrm{C}\right)$ (GDD), Helio thermal units $\left({ }^{0} \mathrm{C}\right.$ day hours) (HTU) and Photo thermal units ( $\mathrm{C}$ day hours) (PTU) required for attainment of phenophases for pearlmillet at different spacings and dates of sowing

\begin{tabular}{|c|c|c|c|c|c|c|c|c|c|c|c|c|}
\hline \multirow{2}{*}{$\begin{array}{l}\text { Growth } \\
\text { Stages }\end{array}$} & \multicolumn{4}{|c|}{$2^{\text {nd }}$ fortnight of July } & \multicolumn{4}{|c|}{$1^{\text {st }}$ fortnight of August } & \multicolumn{4}{|c|}{$2^{\text {nd }}$ fortnight of August } \\
\hline & Phenology & GDD & HTU & PTU & Phenology & GDD & HTU & PTU & phenology & GDD & HTU & PTU \\
\hline \multicolumn{13}{|c|}{$S_{1}(45 \times 15 \mathrm{~cm})$} \\
\hline $\mathbf{G S}_{1}$ & 35 & 688 & 1356 & 8724 & 33 & 669 & 2605 & 8326 & 31 & 624 & 3117 & 7884 \\
\hline $\mathbf{G S}_{2}$ & 68 & 691 & 3977 & 8538 & 66 & 726 & 4102 & 8685 & 63 & 745 & 4505 & 8822 \\
\hline $\mathbf{G S}_{3}$ & 90 & 524 & 2773 & 6166 & 87 & 493 & 3186 & 5713 & 83 & 444 & 2698 & 5081 \\
\hline Total & & 1903 & 8106 & 23428 & & 1888 & 9893 & 22724 & & 1813 & 10320 & 21787 \\
\hline \multicolumn{13}{|c|}{$S_{2}(45 \times 30 \mathrm{~cm})$} \\
\hline $\mathbf{G S}_{1}$ & 33 & 647 & 1244 & 8210 & 32 & 649 & 2476 & 8084 & 30 & 604 & 2962 & 7652 \\
\hline $\mathbf{G S}_{2}$ & 66 & 667 & 3440 & 7652 & 63 & 675 & 4230 & 8090 & 60 & 605 & 4239 & 8299 \\
\hline $\mathbf{G S}_{3}$ & 88 & 528 & 3108 & 6244 & 85 & 474 & 2663 & 5774 & 81 & 454 & 2686 & 4825 \\
\hline Total & & 1842 & 7792 & 22106 & & 1798 & 9369 & 21948 & & 1663 & 9887 & 20776 \\
\hline \multicolumn{13}{|c|}{$S_{3}(60 \times 15 \mathrm{~cm})$} \\
\hline $\mathbf{G S}_{1}$ & 34 & 667 & 1356 & 8643 & 32 & 649 & 2476 & 8084 & 31 & 624 & 3117 & 7884 \\
\hline $\mathbf{G S}_{2}$ & 67 & 672 & 3581 & 7946 & 64 & 700 & 4230 & 8387 & 62 & 726 & 4427 & 8563 \\
\hline $\mathbf{G S}_{3}$ & 89 & 527 & 2995 & 6219 & 86 & 494 & 2843 & 5735 & 82 & 423 & 2588 & 5090 \\
\hline Total & & 1866 & 7932 & 22628 & & 1843 & 9549 & 22206 & & 1773 & 10132 & 21537 \\
\hline \multicolumn{13}{|c|}{$\mathrm{S}_{4}(60 \times 30 \mathrm{~cm})$} \\
\hline $\mathbf{G S}_{1}$ & 33 & 647 & 1244 & 8210 & 31 & 629 & 2304 & 7484 & 30 & 605 & 2962 & 7652 \\
\hline $\mathbf{G S}_{2}$ & 65 & 643 & 3235 & 7353 & 62 & 619 & 3884 & 7435 & 61 & 681 & 4025 & 8051 \\
\hline $\mathbf{G S}_{3}$ & 86 & 507 & 3003 & 6005 & 82 & 461 & 2220 & 5378 & 79 & 419 & 2900 & 5331 \\
\hline Total & & 1797 & 7482 & 21568 & & 1709 & 8408 & 20297 & & 1705 & 9887 & 21034 \\
\hline
\end{tabular}


Table.2 Heat use efficiency $\left(\mathrm{kg} \mathrm{ha}^{-1}{ }^{0} \mathrm{C}^{-1} \mathrm{day}^{-1}\right)$ (HUE), Helio thermal use efficiency (kg ha ${ }^{-1}{ }^{0} \mathrm{C}^{-1}$ day ${ }^{-1}$ hour) and Photo thermal use efficiency $\left(\mathrm{kg} \mathrm{ha}^{-1}{ }^{0} \mathrm{C}^{-1}\right.$ day ${ }^{-1}$ hour)

(PtUE) of pearlmillet at different spacings and dates of sowing

\begin{tabular}{|c|c|c|c|c|c|c|c|c|}
\hline \multirow[t]{2}{*}{ Dates of sowing } & \multirow{2}{*}{$\begin{array}{l}\text { Total } \\
\text { Drymatter }\end{array}$} & \multirow{2}{*}{$\begin{array}{l}\text { Grain } \\
\text { yield }\end{array}$} & \multicolumn{2}{|l|}{ HUE } & \multicolumn{2}{|l|}{ HtUE } & \multicolumn{2}{|l|}{ PtUE } \\
\hline & & & TDM & GY & TDM & GY & TDM & GY \\
\hline \multicolumn{9}{|c|}{$S_{1}(45 \times 15 \mathrm{~cm})$} \\
\hline $\begin{array}{c}D_{1} \text { (2nd FN of } \\
\text { July) }\end{array}$ & 10373 & 2875 & 5.45 & 1.52 & 1.27 & 0.35 & 0.44 & 0.12 \\
\hline $\begin{array}{c}\mathrm{D}_{2} \text { (1st } \mathrm{FN} \text { of } \\
\text { August) }\end{array}$ & 9599 & 2813 & 5.08 & 1.51 & 0.97 & 0.97 & 0.42 & 0.12 \\
\hline $\begin{array}{c}D_{3} \text { (2nd FN of } \\
\text { August) }\end{array}$ & 9018 & 2764 & 4.97 & 1.48 & 0.87 & 0.26 & 0.41 & 0.12 \\
\hline \multicolumn{9}{|c|}{$\mathrm{S}_{2}(45 \times 30 \mathrm{~cm})$} \\
\hline $\begin{array}{l}\text { D }_{1} \text { (2nd FN of } \\
\text { July) }\end{array}$ & 8545 & 1929 & 4.63 & 1.04 & 1.09 & 0.24 & 0.38 & 0.08 \\
\hline $\begin{array}{c}D_{2} \text { (1st FN of } \\
\text { August) }\end{array}$ & 7570 & 1632 & 4.21 & 0.90 & 0.80 & 0.17 & 0.34 & 0.07 \\
\hline $\begin{array}{c}D_{3} \text { (2nd FN of } \\
\text { August) }\end{array}$ & 6511 & 1283 & 3.91 & 0.77 & 0.65 & 0.12 & 0.31 & 0.06 \\
\hline \multicolumn{9}{|c|}{$S_{3}(60 \times 15 \mathrm{~cm})$} \\
\hline $\begin{array}{c}D_{1} \text { (2nd FN of } \\
\text { July) }\end{array}$ & 9658 & 2710 & 5.17 & 1.45 & 1.21 & 0.34 & 0.42 & 0.11 \\
\hline $\begin{array}{c}D_{2} \text { (1st FN of } \\
\text { August) }\end{array}$ & 9339 & 2574 & 5.06 & 1.39 & 0.97 & 0.26 & 0.42 & 0.11 \\
\hline 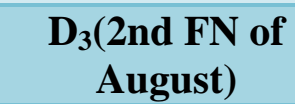 & 8557 & 2447 & 4.82 & 1.38 & 0.84 & 0.24 & 0.39 & 0.11 \\
\hline \multicolumn{9}{|c|}{$S_{4}(60 \times 30 \mathrm{~cm})$} \\
\hline $\begin{array}{c}D_{1} \text { (2nd FN of } \\
\text { July) }\end{array}$ & 7660 & 1675 & 4.26 & 0.93 & 1.02 & 0.22 & 0.35 & 0.07 \\
\hline $\begin{array}{c}D_{2} \text { (1st FN of } \\
\text { August) }\end{array}$ & 6750 & 1245 & 3.94 & 0.72 & 0.80 & 0.14 & 0.33 & 0.06 \\
\hline $\begin{array}{c}D_{3} \text { (2nd FN of } \\
\text { August) }\end{array}$ & 5787 & 1087 & 3.39 & 0.63 & 0.58 & 0.10 & 0.27 & 0.05 \\
\hline
\end{tabular}

From the above study, it can be concluded that $2^{\text {nd }}$ fortnight of July sown crop at $45 \times 15$ $\mathrm{cm}$ spacing performed well by recording maximum GDD, PTU, HUE, HtUE and PtUE with maximum drymatter and grain yields and it could be the optimum time of sowing and optimum spacing for coastal Andhra Pradesh. The present study indicated that the application of heat units provided a scientific basis for determining the effect of temperature and radiation or photo period on phenological behavior of the crop and these indicated very clear picture on the amount, pattern and efficiency of heat energy consumption at different sowing windows and the phenological stages of the crops. 


\section{References}

Bhuva, H.M and Detroja, A.C. 2018. Thermal requirement of pearl millet varieties in Saurashtra region. Journal of Agrometeorology. 20(4): 329-331.

Girijesh, G.K., Kumara, Swami, A.S., Sridhara, S., Dinesh Kumar, M., Vageesh, T.S and Nataraju, S.P. 2011. Heat use efficiency and helio thermal units for maize genotypes as influenced by dates of sowing under southern transitional zone of Karnataka state. International Journal of Science and Nature. 2(3): 529-533.

Haider, S.A., Alam, M.Z., Alam, M.F. and Paul, N.K. 2003. Influence of different sowing dates on the phenology and accumulated heat units in wheat. Journal of Biological Sciences. 3: $932-$ 939.

Iwata, F. 1984. Heat unit concept of crop maturity. Physiological aspects of dryland farming. (Gupta, U.S. ed). Oxford and IBH. pp. 351-370.

Mass, A.L., Hanna, W.W and Mullinix, B.G. 2007. Planting date and row spacing affects grain yield and height of pearl millet Tiftgrain 102 in the South-eastern coastal plain of the United States. SAT eJournal/ ejournal.icrisat.org. 5(1): 1-4.

Nuttonson, M.Y. 1956. A comparative study of lower and upper limits of temperature in measuring variability of day-degree summation of wheat, barley and rye. American Institute of Crop Ecology. Washington D.C.

Padma, S and Subbaiah, G. 2016.
Agroclimatic model for prediction of growth and yield of rice (Oryza sativa L.). M.Sc. (Ag.) Thesis Acharya N.G. Ranga Agricultural University, Rajendranagar, Hyderabad.

Panse, V.G and Sukhatme, P.V.1985. Statistical Methods for Agricultural Workers. ICAR, New Delhi. pp. 100174.

Patidar, N. 2013. Agro climatic model for prediction of growth and yield of rabi maize (Zea mays L.). M.Sc.(Ag.) Thesis Acharya N.G. Ranga Agricultural University, Rajendranagar, Hyderabad.

Railey, K. 2006. Whole Grains Millet (Graminael Poaceae) http/chetday.bcom. Retrieved on 17 June 2009. pp.: 10.

Rajput, R.P. 1980. Response of soybean crop to climatic and soil environments. Ph.D. Thesis. Indian Agricultural Research Institute, New Delhi, India.

Revathi, T and Sree Rekha, M. 2016. Agro climatic indices for prediction of growth and yield of finger millet (Eleusine coracana L.) M.Sc. (Ag.) thesis. Acharya N.G. Ranga Agricultural University, Guntur, Andhra Pradesh.

Wankhede, S.Y., Jadhav, J.D and Shaik, A.A. 2018. Response of pearl millet to heat units under different sowing windows in the scarcity zone of Maharashtra. Contemporary Research in India. 8 (3): 25-29.

www.indiastat.com, 2016-17, Ministry of Agriculture, Government of India 201617.

\section{How to cite this article:}

Swathi, B., V. R. K. Murthy, M. Sree Rekha and JayaLalitha, K. 2020. Response of Pearl Millet to Weather Health Indices under Different Spacings and Sowing Windows in Coastal Agro- Ecosystem of Andhra Pradesh, India. Int.J.Curr.Microbiol.App.Sci. 9(04): 2838-2844. doi: https://doi.org/10.20546/ijcmas.2020.904.332 